\title{
The Transformational Leadership Behavior Of School Principals Of Vocational High Schools In Palembang
}

\author{
Sadrah Ihsani \\ Sriwijaya University \\ sadraihsanisasli@gmail.com \\ Rita Inderawati \\ Sriwijaya University \\ ritarudisaid@yahoo.com \\ Machdalena Vianty \\ Sriwijaya University \\ vianty.unsri@gmail.com
}

\begin{abstract}
The aims of this study were to investigate the description of the transformational leadership behaviour of school principals of private vocational senior high schools in Palembang, and how the school principals implemented the transformational leadership in the school and how the transformational leadership impacted to the teacher performance. The subjects of this study was four school principals of four private vocational senior high schools in Palembang. The data collection was taken from the questionnaire and interview. The data from the questionnaire were analyzed by simple statistical analysis and the interview was analyzed by using thematic analysis. The findings showed that the description of transformational leadership demonstrated the four dimension of transformational leadership, such as idealized influence, inspirational motivation, intellectual stimulation and individual consideration. Later in this study it was found that school principals implement transformational leadership by using some ways such as building the trust, motivation, facilitation and communication. It is also found that the transformational leadership behavior of school principal of private vocational high school in Palembang has an impact to the teacher performance in teaching learning process.
\end{abstract}

Keywords : Leadership; Transformational leadership; Behavior; School Principals; Vocational High School.

\begin{abstract}
Abstrak : Tujuan dari penelitian ini adalah untuk menyelidiki gambaran perilaku kepemimpinan transformasional kepala sekolah dari sekolah menengah kejuruan swasta di Palembang, dan bagaimana kepala sekolah menerapkan kepemimpinan transformasional di sekolah dan bagaimana kepemimpinan transformasional berdampak pada kinerja guru. Subjek penelitian ini adalah empat kepala sekolah dari empat sekolah menengah kejuruan swasta di Palembang. Pengumpulan data diambil dari kuesioner dan wawancara. Data dari kuesioner dianalisis dengan analisis statistik sederhana dan wawancara dianalisis dengan menggunakan analisis tematik. Temuan menunjukkan bahwa gambaran kepemimpinan transformasional menunjukkan empat dimensi kepemimpinan transformasional, seperti pengaruh ideal, motivasi inspirasional, stimulasi intelektual dan pertimbangan individu. Kemudian dalam penelitian ini ditemukan bahwa kepala sekolah menerapkan kepemimpinan transformasional dengan menggunakan beberapa cara seperti membangun kepercayaan, motivasi, fasilitasi dan komunikasi. Juga ditemukan bahwa perilaku kepemimpinan transformasional kepala sekolah pada sekolah menengah kejuruan di Palembang berdampak pada kinerja guru dalam proses belajar mengajar.
\end{abstract}

Kata Kunci : Kepemimpinan; Kepemimpinan Transformasional; Tingkah Laku; Kepala Sekolah; Sekolah Menengah Kejuruan. 


\section{Introduction}

A school principal leadership style plays a role in the improvement of the educational institution. According to Northouse (2016), leadership is a process in influencing a group to achieve common goals. Leadership as a process means that it is not a trait or characteristic that resides in the leader, but rather a transactional even that occurs between the leader and the followers. Likewise, Sashkin and Sashkin (2003) define leadership as the art of transforming people and organizations with the aim of improving the organization's performance. In addition, Koestenbaum (2002) states that leadership is greatness in all one does. Greatness is a style that leaders practice in their daily activities such as: innovativeness, foresight, effectiveness, and flexibility giving high value for people and their willingness to take risk. According to Northouse (2016), there are several types of leadership such as adaptive leadership, authentic, servant leadership, transactional and transformational leadership style. In present this study, the focus of investigation was on one of leadership style namely transformational leadership style.

Transformational leadership is a process in which leaders and followers help each other to advance to a higher level of morale and motivation (Burns, 1978). It means that leaders and followers help each other to advance to a higher level moral and motivation. Furthermore, Northouse (2001), in the simplest terms, describes transformational leadership as the ability to get people to want to change, improve, and be led. It involves assessing associates' motives, satisfying their needs, and valuing them. According to Bass (1998), there are four dimensions of transformational leadership which consist of the following: 1) Idealized influence, the transformational leaders act as role models and display a charismatic personality that influences others to want to become more like the leader, 2) Inspirational motivation, the leaders' ability to inspire confidence, motivation, and sense of purpose of their followers, 3) Intellectual stimulation, the degree to which the leader provides followers with interesting and challenging tasks and encourages them to solve problems in their own way, and 4) Individual consideration, this aspect is representative of leaders who provide a support to individuals need or desire.

McFarlin and Sweeney (1998) claim that the most successful managers in the future should be transformational leaders comprised of strengths, weaknesses and also characteristic behaviors. If leadership is accepted as a process of interaction between leaders and subordinates where a leader attempts to influence the others' behaviors to accomplish organizational goals (Yukl, 2005) then, leaders must foster strong community support for the change by creating a vision for the organization and stimulating them at school (Bass, 1985; 1997). 
In line with transformational leadership theory, Ministerial Regulation of National Education and Culture of Republic Indonesia No 6 Years 2018 about School Principal states that a school principal fully undertakes managerial tasks consisting of the following: 1) Develop entrepreneurship, 2) Supervision to the teachers and educators, and 3) Improving the quality of school based on 8 national education standards. This also works for a school principal of vocational high school because the graduates of vocational high school are ready to contribute to the world of work. Therefore, a school principal of Vocational High School is required to have abilities as change agent, brave and dependable, trust to others, having a role as value-driven, long life learners, visionary (Gafar: 2005, pp 167).

However, some studies that related to the school principals in Indonesian context show that there has been an issue related to the role of school principal. Sofo, et al (2012) classified the major problem of school principal in Indonesia covered three areas: the first problem was the lack of managerial skill at both local government and local schools levels, the second problem was inconsistent changes of education policies especially in national curriculum, and other problem was about the quality of teaching by Indonesia's teachers. In relation to the transformational leadership, the study of Hartinah (2011) showed that school principals' competency, school organizational condition, and work ethic contribute to transformational leadership of school principal.

In relation to the transformational leadership of school principals, this study reported the result of an investigation focusing on the transformational leadership of school principals of Vocational High School in Palembang. Specifically, this study investigated the description of the transformational leadership behavior of school principals of vocational high schools in Palembang, and how do the school principals implement the transformational leadership in the school and impact to the teacher performance.

\section{Research Methods}

This study applied mix method research design. Mixed method is a class of the research where the researcher is combining of both quantitative and qualitative question, method, concept and techniques in a single study (Johnson \& Onwuegbuzle, 2014, pp 113). The quantitative data were derived from questionnaire, while the qualitative data were derived from interview. The quantitative data collection were set the questionnaire addressed to the school principals. The questionnaire were contributed to the four school principals at vocational senior high schools in Palembang. The questionnaire about school principals' leadership style related to transformational. Meanwhile, the qualitative data collection were set an interview addressed to the school principals. 
In analyzing the data, this study employed mixed method data analysis techniques. After the data were collected, the writer would analyze the answer research question. For the questionnaire, the data were measured by a simple statistical analysis that is by calculating the respondents answer from each item and putting the answer in the form of percentage. The distribution of all items on the questionnaire calculated into average. It will be interpreted generally and specifically to answer research question about the description of the transformational leadership behavior of school principals of vocational high schools. For the interview, the researcher began the analysis from the transcriptions of interviews. This qualitative data analysis began with recording the audio taped interview, the data transcribed, coded and analyzed by responses to the research question. Next, the interview were conducted by using thematic analysis, it was connected to answer the research question about how do the school principals implement the transformational leadership in the school and impact to the teacher performance.

\section{Findings And Discussion}

\section{1). The Result of the Questionnaire}

This section presents the result of questionnaire given to the school principals. There were 4 school principals who got involved and completed the questionnaire in this study, (See Table 1)

\begin{tabular}{ccc}
\hline \multirow{2}{*}{ School Principals } & \multicolumn{3}{c}{ Responses } \\
\cline { 2 - 3 } & Yes & No \\
\hline School Principal 1 & $\checkmark$ & - \\
\hline School Principal 2 & $\checkmark$ & - \\
\hline School Principal 3 & $\checkmark$ & - \\
\hline School Principal 4 & $\checkmark$ & \\
\hline
\end{tabular}

Table 1.

School Principals Responses

As described in data collection research instrument, the questionnaire consist of 12 items. These 12 items are grouped into 4 dimensions. (See Table 2).

\begin{tabular}{lc}
\hline \multicolumn{1}{c}{ Factors } & Items \\
\hline Idealized Influence & $1,7,13$ \\
\hline Inspirational Motivation & $2,8,14$ \\
\hline Intellectual Stimulation & $3,9,15$ \\
\hline Individual Consideration & $4,10,16$ \\
\hline
\end{tabular}

Table 2.

Factors and Items of the Transformational Leadership 
To give their responses, the school principals selected one of the following responses: not at all (0), once in a while (1), sometimes (2), fairly often (3) and frequently (4), and the guideline for the scoring is presented in Table 3.

\begin{tabular}{cc}
\hline Score Range & Category \\
\hline $9-12$ & High \\
\hline $5-8$ & Moderate \\
\hline $0-4$ & Low \\
\hline
\end{tabular}

\section{Table 3.}

Categories of School Principals Transformational Leadership Style Scores

If, for example, a school principal number 1 answered Idealized Influence dimension which consisted of items 1, 7 and 13, he would get score 9 . Because the item 1 was scored 4, item 7 was scored 3 and item 13 was scored 2 . Thus, the total score gained by school principal number 1 was 9 , and the range score 9-12 was in high category.

Table 4 presents the 4 school principals' responses. It shows that the 4 school principals demonstrated the 4 dimension of transformational leadership. This is summarizes of school principals responses categorized in 4 dimension of transformational leadership, (See Table 4).

\begin{tabular}{ccc|ccccccc}
\hline \multirow{2}{*}{$\begin{array}{c}\text { School } \\
\text { Principal }\end{array}$} & \multicolumn{8}{c}{ Dimensions of Transformational Leadership } \\
\cline { 2 - 9 } & \multicolumn{2}{c}{ Idealized Influence } & Inspirational Motivation & Intellectual Stimulation & \multicolumn{2}{c}{ Individual Consideration } \\
\cline { 2 - 9 } & Score & Category & Score & Category & Score & Category & Score & Category \\
\hline 1. & 9 & High & 12 & High & 12 & High & 10 & High \\
\hline 2. & 11 & High & 11 & High & 7 & Moderate & 11 & High \\
\hline 3. & 10 & High & 11 & High & 11 & High & 10 & High \\
\hline 4. & 10 & High & 11 & High & 10 & High & 11 & High \\
\hline
\end{tabular}

\section{Table 4.}

\section{School Principals' Responses}

Based on table 4, it can be seen that the dimensions of transformational leadership of four school principals. Overall, the four school principals was in high category. However, individually it can be seen that the school principals' number 2 on the dimension of intellectual stimulation was in moderate category.

\section{2). The Result of Interview}

This section presents the result of interview addressed to the school principals. The purpose of the interview was to find out how the school principals implemented the transformational leadership in the school and the impact of transformational leadership to the teachers' performance. The result of the analysis of the interview were presented in the findings which analyzed by using thematic analysis. The findings is the result of the analysis which are presented based on a themes derived from what the school principals stated. There were building the trust, motivation, facilitation and communication. 


\section{a) Trust}

The majority of four school principals of vocational high school in Palembang agreed that transformational leadership style was implemented through building the trust. The school principals were providing full trust to the subordinates in work to achieved vision and mission of the schools. Four school principals agreed that the important component in leadership is build the trust between leader and subordinates. It can be seen from the responses of the school principals' interview.

Basically, we have to trust in friends. When we do not trust our friends, they are limited in their work. Consequently, all of them are stiff and they think should not be done. If they are given full trust, hopefully they can develop their basic tasks. The point is we have to give full trust to them in work, when they are solve the problem they can decide for themselves. (E).

First of all, we start from ourselves then to the each part subordinates. When we give an example to the subordinates, they are expected to be able to follow our decision. Therefore, it is start from ourselves and do it from a simple thing. (AS).

I build them to serve their work with sincerity in accordance with the purpose of choosing their jobs. Therefore, the subordinate does not work for school principals but for the job chosen. (AN)

We give works to them. We give authority and responsibility. When there are things that do exist that they do well, but there are also still being fostered, attention to the work. (YA).

\section{b) Motivation}

Another ways that the school principals implement the transformational leadership through motivation. Four school principals agreed that motivations as one important ways to exercise the school leadership. Motivation carried a regularly by the school principals in each activity. It can be seen from the responses of the school principals.

I give motivation to subordinates by being invited to discussions related to the work. If they have problems, they are guided; fostered, invited to give each other steps to solve the problems. Then, I always given the motivation to see the friends who work not only work but also have good achievement. In achieving it, I encourage them to comply with regulations, time and obey discipline. When the subordinates have done the above points, as the leader, they should give rewards, so they are motivated, valued for their work not the person. Therefore, the reward is also a mean of motivation for teacher development. (AN) 
All of our outgoing activities always support them, and include their ideas that we might think we can do well. That is the most important thing to give them motivation. To be honest, we have never endured all the activities related to their careers. We give opportunities to take seminars and so on, then what we do here we always give awards. Although, the reward is not in the form of money, but at least congratulation, encouragement. (E)

The most important thing is we give an example that it is impossible for us to just rule without us participating in the work. When there are activities at school, as school principals not only give orders but also have to participate in them so that the work they are responsible for can run well. (YA).

Motivation is important in order that they know duty and responsibility. I am sure that they are aware their responsibility. If they are uncertain, they will have to resign for a number of years. It is mean that it has been natural selection. We have various grades of teacher levels to encourage them to achieve their own resistance by helping them, in the sense if they are bonorarium teachers because there are assessments that must be achieved in the past few years, show the targets and problem are faced by them. Another example, promotions for teachers who have the opportunity to replace certain positions they have experience, otherwise they are not ready. (AS)

\section{c) Facilitation}

The third ways of the school principals implement the transformational leadership style through facilitation. School principals agreed that in encouraging creativity and innovation of subordinates, they must facilitates in their works. As the responses of the school principals:

They are directed at being prepared for the need for creativity. We cannot ask them to be creative if their needs are not prepared. That is knowledge of managing. Creativity needs infrastructure, how to be creative if not facilitated. It is accordance with the cost of the institution. (AN)

Yes to encourage them, one of us did not work with their main task and always think about how their fields are always developed to find out what solutions are better. Sometimes we tell them, the job description that exists does not match what is expected in the field, this is what we do. Please they work, we give them trust and facilitation. (E) Yes, teacher development is the first priority. For example there is training, seminar, competency training. I really prioritized it, there was an assessor who would like to be funded by the school, but after the training I gave a copy because the original was still in school. Because we are private if we give them training and then they go for me to lose and school, then we give a copy. Therefore, the improving teacher quality remains a priority. Now I feel proud, when my teacher has the ability compared to other teachers. (YA) Yes, a simple example such as this teacher, if from the development side, there are stages maybe there are teachers under five years experiences, more than five years or some who 
want retired, certainly different desires. For example, if the new one is pushed to be permanent, then there is also a process called the SIMBASING process, the process can get benefits from our government, which encourages them in order to the criteria. I always encourage them to be able to develop, therefore later on it ends up reaching real income, but the process must be followed. (AS)

\section{d) Communication}

The last ways that the school principals implement the transformational leadership through communication. Good communication between leaders and subordinates not only helps the team to achieve a goal but also helps the organization / school to develop and succeed. The school principal understands the importance of continuous communication with subordinates and it will make school principals understand every need and specific desire of each subordinate. It can be seen from the responses of school principals.

By understanding the characteristic of each subordinates. For example, one social approach, the other being a religious approach, the other might be because it needs to be disciplined with a law approach and a cultural approach. It's true; there are 28 subjects which mean 28 characters. Because every human being is sometimes even though they already have the same rules, because they have to carry out the vision and mission of this institution, but their character is different. Therefore, that's the manager's role as the driver in the school. (AN)

It is not a problem for me. Personally, the point is I say while we are able to do it, while we can and there is an impact for us and children, please do it. Sometimes we give, what I said before, we are given they are trust, we must believe in subordinates. But the trust that we give is always in our monitoring. (E)

Yes, each of subordinates have different need and desires. For example, they asked about students' graduated uniform party etc. I tell the important thing is that you teach well that's enough of me, the school principal is always thinking about your welfare. (YA)

It is certain that everyone must have different needs. The point is, we must interpret each of these jobs and understanding each job is indeed a part of the life. In education, we must understand a problem that is as part of the educational process. Therefore, each individuals may be different need and desire. (AS)

In order transformational leadership of the school principals in impact to the teacher performance, the writer concluded that school principals' transformational leadership principals inspire the teacher to help in solving problem. Moreover, the school principals facilitates the teachers in their creativity and innovation in their teaching process.

It can be seen from the responses of the school principals:

Sometimes in a simple forum, we give an example. For example, they deliver the problem, sometimes we solve it together. Even if they may have ideas, and those ideas are included in the conversation, maybe we can provide input that might be suitable for him. When in 
the forum they convey the problem, we try to find a solution together. This means that the teacher does not live it alone, it can be with the help of the principal. (E)

Yes, it's here in terms of the teaching and learning process then there is supervision. We are supervised by the supervisor. When I say about the follow-up, I will give an example what should they do. I will help the teacher to solve the problem. Therefore, the inspiration for the work is indeed for each activity of the teacher in the school. (YA)

Yes, an inspiration is just stimulation. We have years of experience, the problems they face are not much different from us. Therefore, the first thing is build his own awareness and staying it. Actually they already know how to solve it, sometimes they needs affirmation of us as a leader in the school. So I really have to inspire a position as a leader. It must be delivered only for comparison to the problems they faced in the teaching process. (AS)

Another answered that the school principals encourage the subordinates to be creative and innovative by facilitating their needs. We cannot ask teachers or subordinates to work properly without facilitating them and providing all their needs.

They are directed at being prepared for the need for creativity. We cannot ask them to be creative if their needs are not prepared. That is knowledge of managing. Creativity needs infrastructure, how to be creative if not facilitated. It is accordance with the cost of the institution. (AN)

Yes to encourage them, one of us did not work with their main task and always think about how their fields are always developed to find out what solutions are better. Sometimes we tell them, the job description that exists does not match what is expected in the field, this is what we do. Please they work, we give them trust and facilitation. (E)

As stated in the findings, overall the result of the investigation of the transformational leadership of four school principals showed in high category. There were idealized influence, inspirational motivation, intellectual stimulation and individual consideration. For the dimension of idealized influence, it show that the school principals of four vocational high schools are able to be a model for their subordinates. The school principals gives a strong influence in delivering the visions and missions of the school. Furthermore, for the inspirational motivation of the school principals, it is represents that the school principals' leadership are able to be a motivator for their subordinates. The school principals' motivation by giving reward in supporting performance of the subordinates. It is line with (Burn, 1978) state that transformational leadership is a process whereby a person engages with others and creates a connection that raises the level of motivation and morality in both the leader and the followers. It is mean that both the leaders and subordinates engage to each other and create a good relationship to improve the level motivation, moral.

Regarding the other dimension of transformational leadership about individual consideration of the school principals, it is represent that the school 
principals' leadership are able to understand the subordinates desire and specific needs. It is mean that the school principal pay attention to each individual subordinates needs for achievements and growth by acting as a coach or mentors. The school principals' leadership are able to encourage the subordinates to be creative and innovative. Therefore, the subordinates are able to develop creativity in completing their task. It is line with Komariah and Cepi Triatna (2008, pp, 79-80) state that the school principal as an intellectual leader must encourage the subordinates to be creative and innovative in completing their task. It is mean that the school principal encourage creativity and innovation by providing facilitates the subordinates' needs.

However, the result of investigation of the questionnaire individually showed that the school principal number 2 was in moderate category for intellectual stimulation dimension. In this dimension, the school principal encourages the subordinates to be creative and innovative. It is supported by the result of the interview to the school principals number 2 , it showed that the school principal number 2 has financial limitation that provided by organization. It is mean that the school principal is limited in facilitating the needs of subordinates. This also be seen from the results of the accreditation for SMK levels in Palembang. For the items 106 state that (the school spend the cost for developing educators based on RKA for the last 3 years) showing in number 3 of 4. It is mean that in supporting the educators, the school only at the level middle because the school principals has limited in encouraging creativity and innovativeness of the subordinates.

As stated above, the description of transformational leadership of four school principals of four vocational high school in Palembang demonstrated the four dimension of transformational leadership. It is line with (Popper, Mayselles \& Castelnovo, 2000), there are four major aspects of transformational leadership such as idealized influence, inspirational motivation, intellectual stimulation and individual consideration. Furthermore, it is supported the study from (Ismaya, $B$, 2017), she claimed that high level of characteristics of transformational leadership in terms of idealized influence, inspirational motivation, individual consideration and intellectual stimulation behaviors. Therefore, the transformational leadership style of the school principals demonstrated the four dimension of the leadership style.

As a leader in the school, the school principals of four vocational high schools employs four ways in implementing transformational leadership style in the school. First, the school principals implement the transformational leadership by building the trust. The school principals give trust by providing responsibility and authority of subordinates in their work. In line with Brower et al (2009), they point out that trust in leadership is important element in supervisor and subordinates relationship. It is mean that the school principals to 
build full trust in works because the trust between leaders and subordinates has a positive relationship in achieving vision and mission of the school.

Furthermore, the school principals should not only gain the trust of their subordinates but also try to trust the subordinates. For example, the study from Kim, Wang and Chen (2016) did the research about Mutual trust between leader and subordinates and employee outcomes. The result of the study showed that a positive effect perceived mutual trust on task performance and interpersonal facilitation after controlling for trust in leader and felt trust. In addition, the study from Yasir et al (2016) states that a positive relationship between transformational leadership and employees' trust in the leader. It is mean that, mutual trust between leader and subordinates that will increased their works. Therefore, the mutual trust between the leader and subordinates will create a good relationship in achieving vision and mission of the school.

Second, the school principals implement the transformational leadership through motivation. The school principals provide motivation as a part of their leadership. The main point is motivation as a support for subordinates to achieve a common goals. By providing motivation of the school principals, it will help the subordinate's performance will be better. It is line with Robbins (2003) stated that, motivation is a factor that moves people act, as the psychological factors can grow due to the demands of the fulfilment of the requirement. It is mean that motivation is the factor to grow people or organization in their work. Therefore, the school principals' motivation has an important role in the performance of the subordinates.

Furthermore, school principals' motivation will improve subordinates performance. For example, the study from Ngaithe, K'Aol, Lewa and Ndwiga (2016) they point out that inspirational motivation had a positive effect on staff performance. Therefore, in improving staff performance in their work because motivation and subordinates performance has a positive relation too. In addition, Salleh, Dzulkifli, Abdullah and Yakoob (2011) they point out that affiliation motivation is positively associated with job performance. It is mean that, increasing school principals' motivation will followed increased to the subordinates' performance.

The next ways in implementing the transformational leadership of school principals was facilitation. A school principals agreed that creativity and innovation is important for the subordinates. The school principals provide facilitates in order creativity and innovation. In encouraging the creativity and innovation of the subordinates, school principals not only order the creativity but also facilitates their needs. An example, the school principals facilitates by providing tools to support the teaching process. As stated the study from Ogola, Sikalieh \& Linge (2017) they said that better performance is achieved when employees are encouraged to re-examine assumptions, critically think when 
solving problem and use creativity and innovation when doing their work or assignments. Therefore, the point is in order creativity and innovativeness the school principals provide the facilitation to the subordinates. They usually facilitate their needs and provide guidance for the subordinates.

The other ways was communication. The school principals use communication as one of ways to understand their subordinates need or specific needs. The effective and accurate communication is the important factors in success of the school principals in the school. In line with Keyton (2011) state that communication as the process of transmitting information and common understanding from one person to another. Therefore, the school principals must have good communication skill to be efficient and effective in leading the school. It is line with study from Flauto (1999), he claimed that communication competence is a prerequisite for effective leadership, each of leadership dimension, was highly correlated with communication competency. Moreover, the study from Wikaningrum, Yuniawan (2018) states that leadership style and communication skills have a significant effect on employee satisfaction. Therefore, a good communication between the school principals and subordinates will create a good relationship in the school environments.

Furthermore, the transformational leadership of school principal has an impact to the teacher performance. Based on the analysis of the interview, it can be seen that the school principals' leadership help the teacher in teaching process. It is start from helping the teacher to solve the problem and facilitates their needs. It is mean that the leadership style of the school principals will contribute to the performance of individual subordinates. It is line with to Gibson et al 2008, there three groups of variables as factors that can affect the performance of potential of individuals within the organization, 1) individual variables such as: a). ability and skill, b). family background, social level and experience; 2) organization variables such as: a). resources, b). leadership, c). reward, d). structure, e). design of job; psychology variables such as: a). mental/intellectual, b). perception, c). attitude, d). personality, e). study, f). motivation. From these explanation above, it can be seen that leadership style is part of the factors that affect to the performance of individuals. It is mean that the leadership style of a leader that will have an influence on the performance of each individual or subordinates. Therefore, a good leadership style will improve the performance of individual or subordinates.

Moreover, study from Munawaroh (2011) states that the transformational leadership style partially is have a significant effect on the performance of teacher at Wajana Jombang Junior high school. If the school principals is tends on a transformational leadership that recognized as an effective leadership style, therefore it is also followed by higher teacher performance. It is also line with study from Andriani, Kesumawati, Kristiawan 
(2018) that said transformational leadership has a positive and significance effect on the teachers' performances. It is supported by the study from Alzoraiki, Mutalib, Rahman (2018) states that all the dimensions of transformational leadership have a positive influence on the teacher performance. Therefore, in increasing transformational leadership of school principal will be followed to the teachers' performances.

\section{Conclussion And Suggestion}

The result of the study above can be concluded that first, the description of transformational leadership of the school principals demonstrated the four dimension of transformational leadership, such as idealized influence, inspirational motivation, intellectual stimulation and individual consideration. Second, there are four ways for school principals to implement the transformational leadership, such as building the trust, motivation, facilitation and communication. Third, the transformational leadership of the school principals has an impact to the teacher performance. In increasing transformational leadership of school principal will be followed to the teacher performance. Based on the findings and conclusions above, the writer would like to give several suggestions. Since this research only focusses on the description of transformational leadership of the school principals, it is hoped that other writers are suggested to investigation transformational leadership in impact to the teachers of English in the school. Second, the writer are suggested to investigation the description of transformational leadership of the school principals based on other perspective, such as teacher or staff perspective.

\section{References}

Alzoraiki, M., Mutalib, M. A., Abrahman, O. (2018). The Effect of the Dimensions of Transformational Leadership on the Teachers'Performance in the Yemeni Public School. European Scientific Journal, 14 (25).

Andriani, S., Kesumawati, N., Kristiawan, M. (2018). The Influence of the Transformational Leadership and Work Motivation on Teachers Performance. International Journal of Scientific and Technology Research, 7 (7), 19-29.

Bass, B. M. (1985). Leadership and performance beyond expectations. New York, NY: Free Press.

Bass, B. M. (1998). Transformational Leadership: Industry, military, and educational impact. Mahwah, NJ: Erlbaum.

Brower, H. H., Lester, S. W., Korsgaard, M. A., \& Dineen, B. R. (2009). A Closer look at trust between managers and subordinates: Understanding the effects of both trusting and being trusted on subordinate outcomes. Journal of Management, 35(2), 327-347. 
Fathurrochman, I., \& Budiman, D. A. Alamsyahril, \& Kristiawan, M.(2019). Revitalization Management of Islamic Boarding School Preventing The Radicalism. Restaurant Business, 10, 495-505.

Flauto, F. J. (1999). Walking the Talk: The relationship between leadership and communication competence. Journal of Leadership and Organizational Studies, 6 (2), 86-97.

Gaffar, M. F. (2005). Perencanaan Pendidikan: Teori dan Metodologi. Jakarta: P2LPTK Depdikbud.

Gibson, J. L., Ivancevich, J. M., \& Donelly, J. H. (2008). Organisasi, Perilaku, Struktur, dan Proses. Jakarta: Binaputra Aksara Publisher.

Hartina, S. (2011). Model kepemimpinan transformasinal kepala sekolah SMK negeri. Jurnal Pendidikan dan Kebudayaan, 17 (1), 12-28.

Ismaya, B. (2017). The Implementation of Transformational Leadership in Developing Academic Quality. Educational Administration Review, 1 (1), 53-57.

Johnson, B., \& Onwuegbuzie, A. (2004). Mixed methods research: A research paradigm whose time has come. Educational Research, 33 (7), 14-26.

Kemdikbud. (2018). Peraturan menteri pendidikan nasional republik Indonesia nomor 6 tahun 2018 tentang penugasan guru sebagai kepala sekolah. Menteri pendidikan Nasional. Jakarta. Retrieved from https://jdih.kemdikbud.go.id/arsip/Permendikbud_Nomor6_Tahun2018. pdf.

Kemendikbud. 2017. Peraturan menteri pendidikan dan kebudayaan nomor 5 tahun 2017 tentang kriteria dan perangkat akreditasi sekolah menengah kejuruan. Jakarta: Menteri Pendidkan Nasional.

Keyton, J. (2011). Communication and Organizational Culture: A key to understanding work experience. Thousand Oaks, CA: Sage.

Kim, T, Y., Wang, J., \& Chen, J. (2016). Mutual Trust Leader and Subordinate and Employee Outcomes: Journal of Business Ethics, 1-17.

Koestenbaum, P. (2002). Leadership: The inner side of greatness. A philosophy for leaders. Jossey-Bass, San Francisco.

Komariah, A. \& Triatna, C. (2008). Visionary Leadership Menuju Sekolah Effectif. Jakarta: Bumi Aksara.

McFarlin, D. B., Sweeney, P. D. (1998). International management: trends, challenges and opportunities, Ohio: South-Western College Publishing. 
Munawaroh. (2011). Pengaruh Kepemimpinan Transformasional dan Transaksional Terhadap Kinerja Guru. Jurnal Ekonomi Bisnis, 16 (2), 136144.

Ngathe, L., K'Aol, G., Lewa, P., Ndwiga, M. (2016). Effect of idealized influence and inspirational motivation on staff performance in state owned Enterprises in Kenya. European Journal of Business and Management, 8 (30), 6-13.

Nilwala, N., Fernando, R. L. S., \& Gunawardana, K. (2017). Scale for Measuring Transformational Leadership in Public Sector Organization in Sri Langka: with special reference to ministries of western provincial council. International Journal of Management and Sustainability, 6 (4), 63-74.

Northouse, P. G. (2016). Leadership: theory and practice (7th edition). United States: Western Michigan University.

Ogola, M. G. O., Sikalieh, D., Linge, T. K. (2017). The Influence of Intellectual Stimulation Leadership Behaviour on Employee Performance in SMEs in Kenya. International Journal of Business and Social Science, 8 (3), 89-100.

Popper, M., Mayseless, O. \& Castelnovo, O. (2000). Transformational leadership and attachment. Leadership Quarterly, 11(2), 267-289.

Salleh, F., Dzulkifli, Z., Abdullah, W. A.W., \& Yakoob, N. H. M. (2011). The Effect of Motivation on Job Performance of State Government Employees in Malaysia. International Journal of Humanities and Social Science, 1 (4), $1-8$.

Sashkin, M., \& Sashkin, M. (2003). Leadership that Matters. San Francisco: Berret Koehler publishers inc.

Sofo, F., Fitzgerald, R., \& Jawas, U. (2012). Instructional leadership in Indonesian school reform: overcoming the problems to move forward. School Leadership \& Management: Formerly School Organisation, 32 (5), 503-522.

Wikaningrum, T., \& Yuniawan, U. A. (2018). The Relationship among Leadership Style, Communication Skills, and Employee Satisfaction: A study on equal employment opportunity in Leadership. Journal of Business and Retail Management Research, 13 (1), 1-10.

Yasir, M., Imran, R., Irshad, M. K., Mohamad, N. A., \& Khan, M. M. (2016). Leadership Style in Realtion to Employees'Trust and Organizational Change Capacity: Evidence from non-profit organizations. Sage Open, 112. 
132 | TADBIR : Jurnal Studi Manajemen Pendidikan, Vol. 4, No. 1, Mei 2020

Yukl, G. A. (2005). Leadership in organizations, Ninth Edition, Prentince Hall. 